\title{
Do State Pension Investments Generate Positive Alphas?
}

\author{
Martin Hanby \\ Texas A\&M University
}

Anthony L. Fulmore, Sr.

Texas A\&M University

\author{
Srinidhi Kanuri \\ University of Southern Mississippi \\ Robert McLeod \\ University of Alabama
}

\begin{abstract}
In our initial analysis of the state pension investment return data set we found that investments outperformed many market indices on both an absolute and risk adjusted basis. Our goal in this paper was to confirm our prior findings using several models including the Capital Asset Pricing Model, Fama French three-factor, and five-factor models and the Carhart four-factor model. We regressed our equal-weighted and weighted-average pension investment return data on each of the models. All our regressions produced positive and significant alphas. We then performed panel regressions using the individual returns from all 85 pension plans in our data set against the same set of models. Again, we found positive and significant alphas using both models. Finally, we employed a bootstrapping procedure to confirm that alphas in our time series regressions were positive and significant. We find that state pension plans do generate positive alphas.
\end{abstract}

Keywords: state pension investment returns

\section{INTRODUCTION}

In our initial analysis of the state pension investment return data set we found that investments outperformed many market indices on both an absolute and risk adjusted basis. In this paper our analysis will focus on $\alpha$ because $\alpha$ is the most widely accepted measure of investment performance in the market today. If our regressions generate positive $\alpha$, it is a clear sign that state pension plan investments are outperforming the market. We use the Capital Asset Pricing Model (CAPM), the Fama French three-factor and five-factor models and the Carhart four-factor model to thoroughly analyze our state public pension investment returns and confirm that the pension plans in our data set had outperformed the market. The CAPM was developed by Sharpe (1964), the model is widely considered to represent the market. The Fama French model goes beyond the market and incorporates factors which capture excess returns associated 
with firm size, book-to-market value, profitability and investment type, conservative vs. aggressive, Fama and French (2015) and the Carhart model developed by Carhart (1997) incorporates momentum to the Fama French three-factor model. In this paper, we examine the same state pension plan investment returns from the years ending June $30^{\text {th }}$, 2001 through 2014 using the five models described above.

The failure to achieve assumed investment returns and the resulting funding shortfalls of defined benefit pension plans have been well documented and pose a serious challenge at just about every level of government in the United States. One significant issue with defined benefit plans is that the plan sponsor typically takes all investment risks. Notable examples of underfunded pension plans at the federal level are the U.S. Postal Service and the Social Security Administration. Cities such as Chicago, Detroit, and Philadelphia face unfunded pension liabilities that are so large that they are unlikely to be able to fully fund these liabilities. Even more important, deposits to pension systems are becoming a drain on government budgets at every level and forcing significant reductions of essential government services like fire protection and law enforcement. Finally, we calculate that as much as $75 \%$ of the shortfall is due the failure to achieve assumed rates of return.

\section{PRIOR LITERATURE}

Sharpe (1964) developed the CAPM, the model explains over $80 \%$ of diversified equity portfolio returns. Fama and French (1993 and 2015) developed and expanded a framework that has enhanced the explanatory ability of the CAPM to explain equity returns. The three-factor model adds firm size and bookto-market to the CAPM. The theories behind these two factors respectively are that small cap firms outperform large cap firms and firms with high book-to-market or undervalued firms tend to outperform high book-to-market firms. The five-factor model adds factors for conservative vs. aggressive investment firms and profitability to the three-factor model. The respective theories are that conservative investment firms outperform aggressive firms and that firms that have recently been profitable will outperform recently unprofitable firms. Carhart (1997) looks at persistence in equity mutual funds and risk-adjusted returns. The Carhart four-factor model adds a momentum factor to the Fama French three-factor model. The Fama French and Carhart models explain $90 \%$ or more of diversified portfolio returns. All the models described above are used to benchmark investment performance.

Public Pension investment performance has not been a prominent topic in recent literature, but public pension portfolio allocations have received significant attention recently. Andonov, Bauer and Cremers (2014) found that public pensions in the US had increased allocations to risky assets over the past several decades to achieve higher discount rates. Pennacchi and Rastad (2011) examined the portfolio allocation policies of state and local pension funds and found that optimal portfolio allocations are derived when pension fund management maximize the utility of wealth of a representative taxpayer or when pension fund management maximize their own utility of compensation. Additionally, they found evidence that funds chose greater overall portfolio risk following periods of relatively poor investment performance and pension plans take more risk when they have greater representation by plan participants on their Boards of Trustees. Mohan and Zhang (2014) found that government accounting standards strongly affect public fund investment risk, as higher return assumptions are associated with higher equity allocation and beta. They also found that public funds take more risk if they are underfunded and have lower investment returns in prior years. Hanby, Tenant, Kanuri and McLeod (2019) examined the difficulties that state encounter when they attempt to implement reforms. They found that reforms are significantly restricted once participants are hired.

\section{PENSION FUNDING}

Problems with pension funding started prior to 1985 , when many state pension plans operated on a pay as you go basis. This system worked well if the number of covered employees and thus their payrolls were increasing over time. During the late ' $70 \mathrm{~s}$, inflation and payroll growth easily met the cash flow needs of the retirees. The pension funding situation began to change when the growth of state government 
employment slowed, which was originally due to slower population growth and more recently due to state budgetary shortfalls. In 1985 the Governmental Accounting Standards Board (GASB) was created. The GASB established new guidelines for recognizing and funding pension obligations, which were first implemented in the 1986 reporting year. At that time GASB offered some flexibility as to how each state would amortize its pension obligations. First, states could select any amortization period up to a maximum of 40 years and many immediately selected a 40-year amortization period. In addition, states selected a method of calculating amortization payments from the following two options: (1) level percent of payroll, which calculates amortization payments as a constant percentage of projected payroll over a given number of years, and the more conservative and initially costlier (2) level dollar amortization methodology, which amortizes the cost into equal dollar amounts to be paid over a given number of years. The combination of the 40-year amortization and level percent of payroll method resulted in significantly lower required contributions and a negative amortization of pension liabilities for at least 10 years. So, for the first decade states were supposed to be addressing pension funding while most were just passing the funding problem on to the next generation.

GASB Statement 25 reduced the 40-year maximum amortization to 30 years for accounting periods after June 15, 1996. Other issues arose that needed to be addressed including spiking and re-amortization of the UAAL. Spiking occurs when an employee's salary increases significantly in the final years of his or her employment. The result can create a large increase in the pension plan's liability that is greater than has been provided for by the contributions over the term of employment. Re-amortization is simply recalculating and extending the payments required to amortize the UAAL. Almost all states do it; some states do it every few years while some would do it every year. The practice and financial impact are examined in detail by Munnell, et al (September 2014). As an example, that is comparable to how states were treating their pension funding, imagine refinancing a 30-year mortgage once a year with another similar 30-year mortgage. One would always be starting a new mortgage at the first payment, which amortizes almost no principal. One would never pay off the mortgage and there's a of negative amortization where one would end up owing more than the original loan amount due to the necessary payment of closing costs for each new mortgage. A key problem was the fact that there are no limits on re-amortization unless they are imposed by each individual state.

The unfunded pension liability issue was masked somewhat by the high stock market returns of the mid to late 1990s. During this time, many states elected to give plan members unfunded benefit increases and allowed the taking of contribution holidays. A contribution holiday is simply not making the necessary ARC to sustain the plan and were commonplace. More recently pension holidays have been taken by states out of necessity rather than by choice. For example, New Jersey and Pennsylvania made only 39\% and 43\% of their respective ARCs during 2012 (Pew Charitable Trusts, March 2014).

Pension funding issues have now been fully exposed starting with the 2001 recession, which included declines in interest rates and stock market returns. Pension plans were dealt another setback during the financial crisis of 2008, due to similar declines in interest rates and the stock price decreases were much more severe than those that occurred during the previous recession. Historically portfolio allocations roughly $60 \% / 40 \%$, plans would invest around $60 \%$ of their assets in equities and the remaining $40 \%$ of their assets in fixed income securities; however, allocations began to change in the 1990s due to declining interest rates and an increasing number of investment alternatives. Declines in interest rates have had an impact on the plans in our data set; the average fixed income allocation was over $31 \%$ in 2001 and the allocation had fallen below $15 \%$ in 2014 .

This change is not a surprise as interest rates have been extremely low since the 2008 recession and many states were below historical averages for much of the time between the 2001 and 2008 recessions. This new riskier portfolio allocation places more importance on equity returns which can be more volatile than fixed income investments.

As a result, pension assets only grew about 35\% between 2001 and 2013 while pension obligations have grown approximately $90 \%$ over the same period. Figure 1 shows the value of pension assets and liabilities during this period. The gap between assets and liabilities has significantly increased over time. It 
is also worth noting that many plans utilized asset smoothing during this time, which tends to mask market volatility and presents a picture that appears to be much more stable than the actual results that occur.

\section{FIGURE 1}

\section{HISTORICAL PENSION ASSETS AND LIABILITIES FROM 2001 TO 2014}

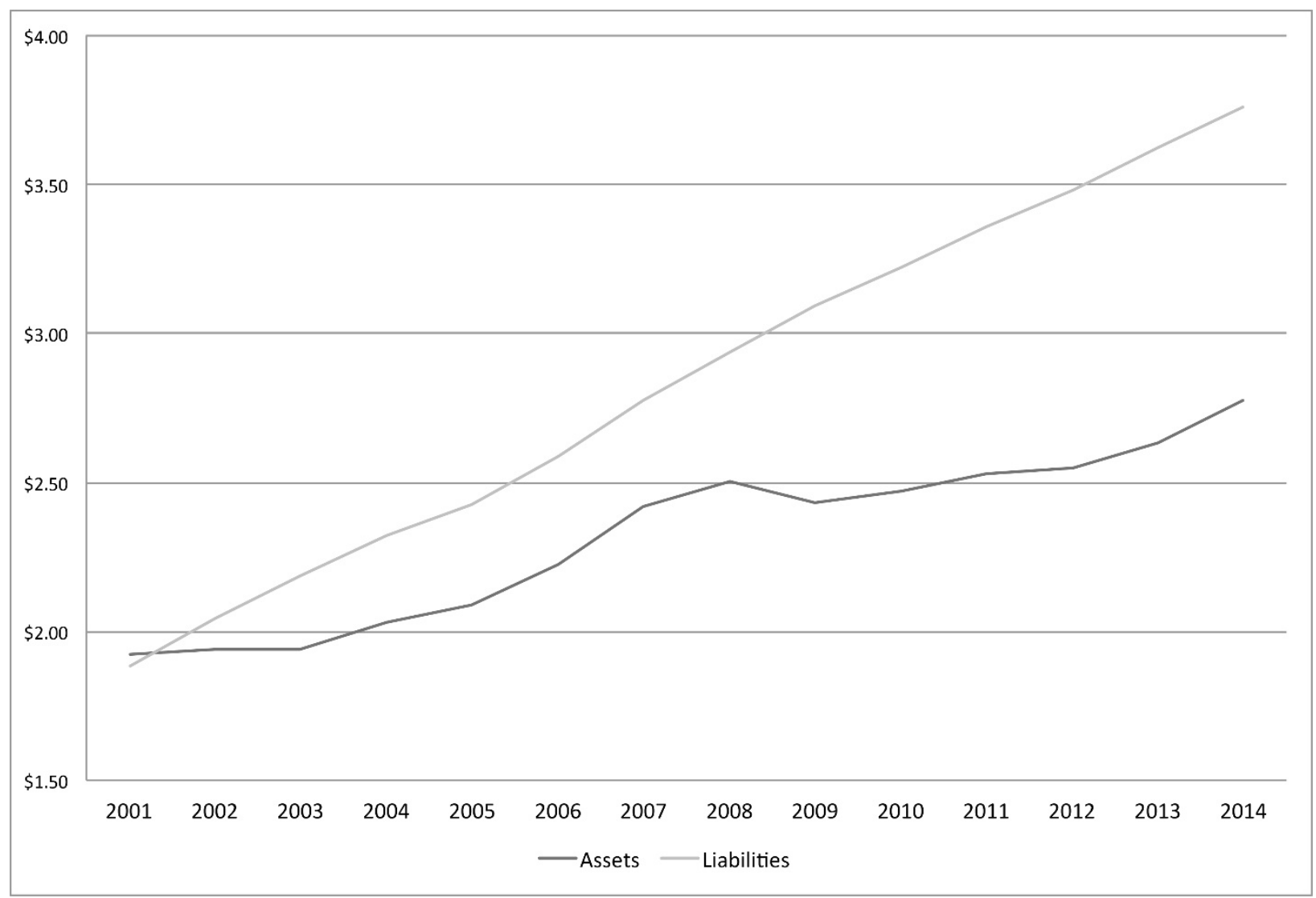

Source: Public Plans Database. 2001-2014. Center for Retirement Research at Boston College, Center for State and Local Government Excellence, and National Association of State Retirement Administrators.

Figure 2 shows pension assets and UAALs in billions of dollars for all fifty states. The assets are indicated in blue while the UAALs indicated in red. It is evident that California, Illinois, and Ohio comprise a significant portion of the funding problem; however, the funded ratios are quite low in most states. Figure 3 shows the pension assets and liabilities on a relative basis. The blue area in Figure 3 is representative of the funded ratio for each state. Only two states, Tennessee, and Wisconsin, were fully funded as of their 2014 reports. 
FIGURE 2

STATE PENSION ASSETS AND LIABILITIES IN MILLIONS FOR 2014

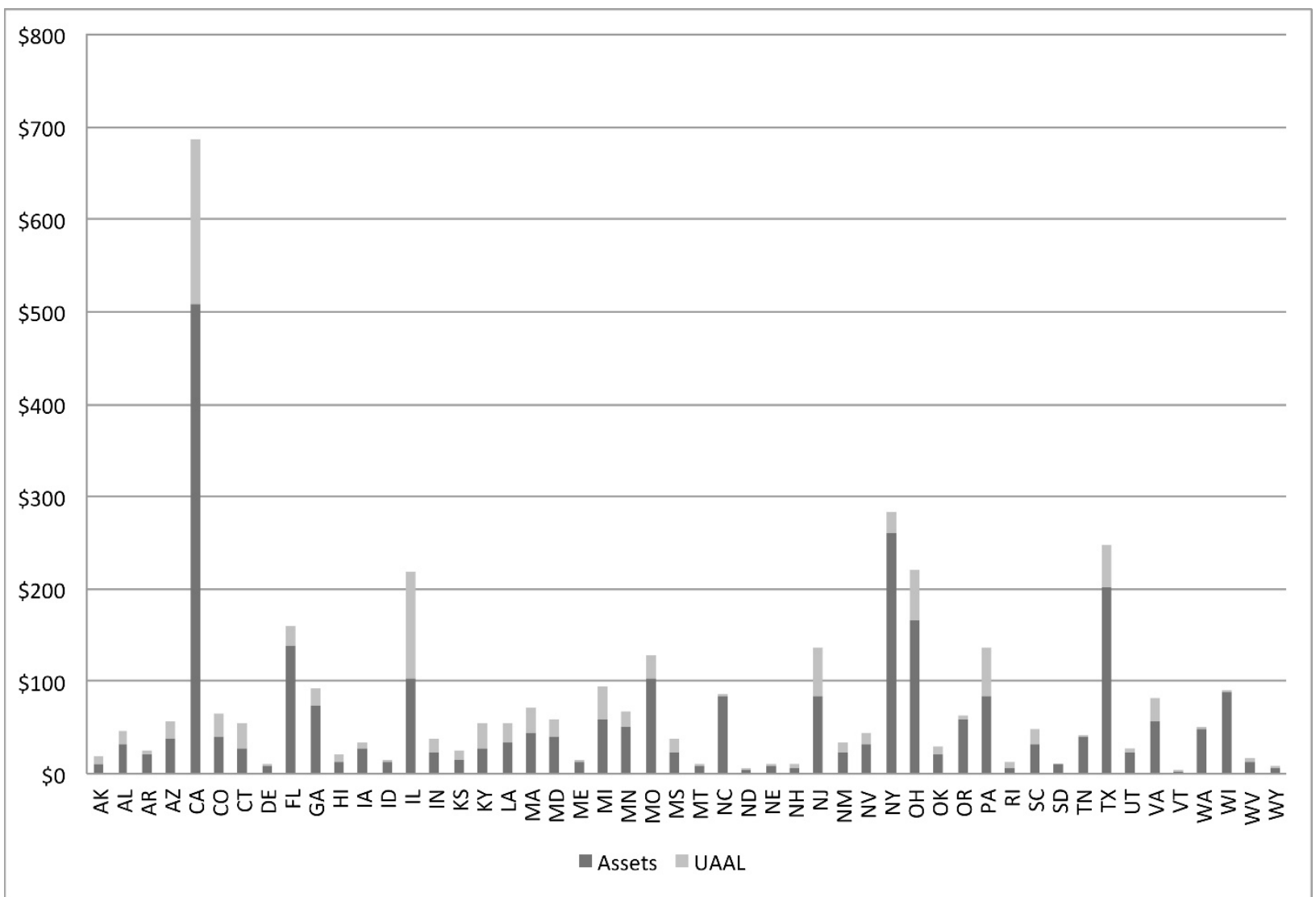

Source: Public Plans Database. 2014. Center for Retirement Research at Boston College, Center for State and Local Government Excellence, and National Association of State Retirement Administrators.

Figure 3 shows a clearer picture of the significance of the UAAL in almost every state in the country. 
FIGURE 3

STATE PENSION ASSETS ON A RELATIVE BASIS FOR 2014

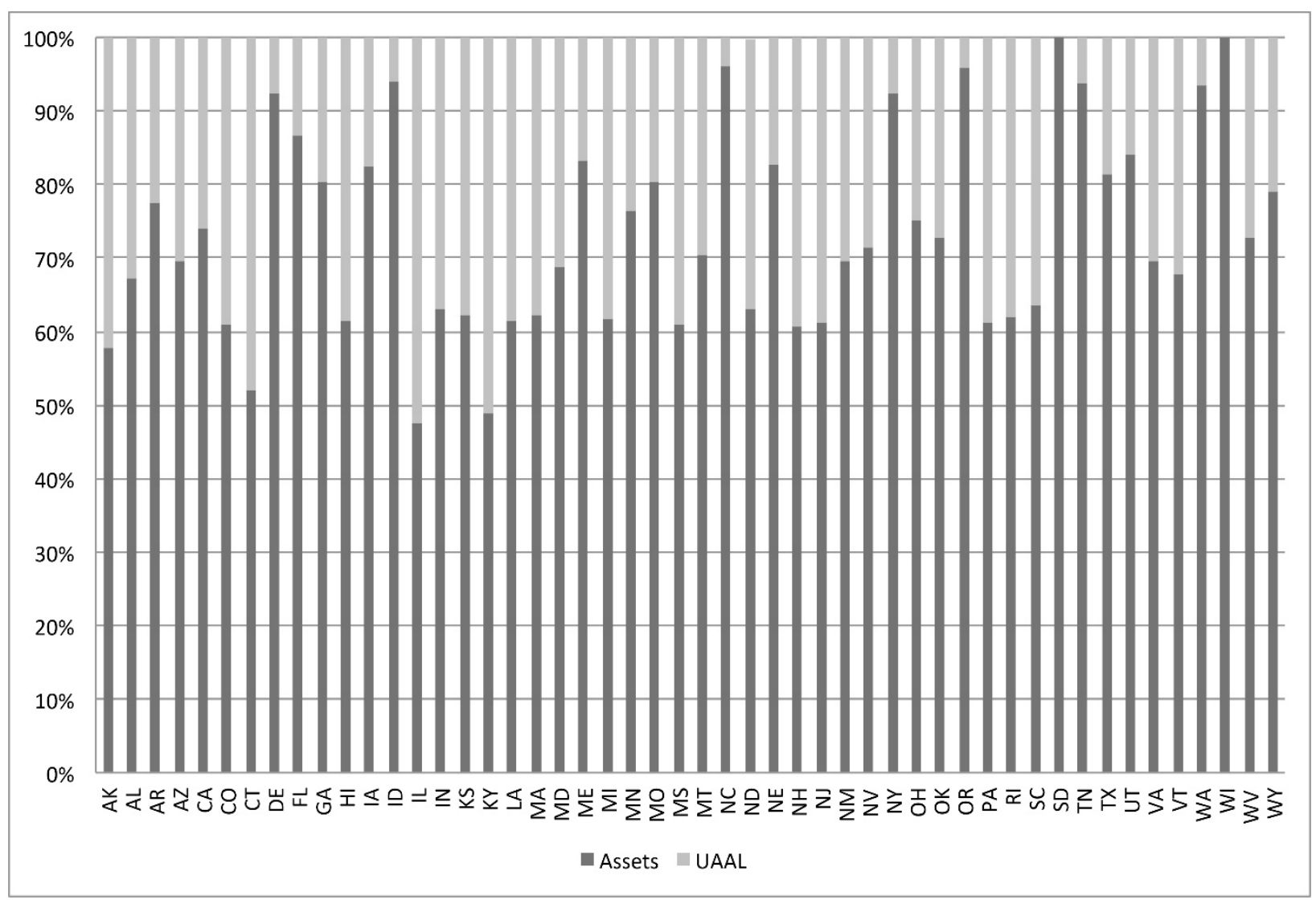

Source: Center Public Plans Database. 2014. Center for Retirement Research at Boston College, Center for State and Local Government Excellence, and National Association of State Retirement Administrators.

\section{DATA}

The source for our pension return data is the Public Plans Database from the Center for Retirement Research at Boston College. We removed all non-state pension plan data from the file; there are 115 state pension plans in the database. Finally, to create a uniform sample, we removed all plans that did not have a June $30^{\text {th }}$ fiscal yearend; this adjustment reduced our sample size to 85 . The Fama French data was downloaded from Kenneth French's personal website and the Carhart data was downloaded from the WRDS database.

\section{METHODOLOGY}

We examined the historical asset returns of state public pension systems; we attempted to determine whether they are producing value or above market returns for their members, i.e., generating positive alphas. Another way to phrase the question; are the plans able to consistently beat the market.

Performance $(\alpha)$ for our public pension investment returns is computed using the following five models; the Capital Asset Pricing Model (CAPM), the CAPM with the Barclays Aggregate Bond Index, the Fama French three-factor and five-factor models, and the Carhart four-factor model as discussed in the following sections. 


\section{Capital Asset Pricing Model}

The CAPM was developed by Sharpe (1964) and this model is used to address the problem of evaluating a plan's performance. In our case, the performance of plan's investments is represented by $\alpha$ which represents the return after adjusting for systematic risk. The model is specified as:

$R_{t}-R_{F t}=\alpha+\beta\left(R_{M t}-R_{F t}\right)+e_{t}$

We set $r_{t}=R_{t}-R_{F t}$, which is the mean excess return for all of the plans in our data set at time $\mathrm{t}, \alpha$ is the intercept term, $\beta$ is the standardized regression weight. A positive intercept $(\alpha)$ indicates that the plan has outperformed the market through superior asset selection ability. In addition, we added the Barclays Aggregate US Bond Index to the CAPM to determine if fixed income investments were having an impact on alpha. The model is specified as:

$R_{t}-R_{F t}=\alpha+\beta\left(R_{M t}-R_{F t}\right)+b$ Bonds $+e_{t}$

\section{Fama French Models}

We conduct our analysis using the Fama French three-factor and five-factor models using the cumulative value-weighted and equal-weighted returns from the 85 state pension plans that report annually on June $30^{\text {th }}$. Our Fama French five-factor time series model is as follows:

$R_{t}-R_{F t}=\alpha+\beta\left(R_{M t}-R_{F t}\right)+s S M B_{t}+h H M L_{t}+r R M W_{t}+c C M A_{t}+e_{t}$

We set $r_{t}=R_{t}-R_{F t}$, where $R_{t}-R_{F t}$, which is the mean excess return for all of the plans in our data set at time $\mathrm{t}, \alpha$ is the intercept term, $\beta$ is the standardized regression weight, $S M B_{t}, H M L_{t}, R M W_{t}$, and $C M A_{t}$ are the Fama French factors representing diversified zero investment portfolios which capture the impact of small cap stocks, high book to market or value firms, profitability and conservative vs. aggressive investment firms or risk taking on the returns, respectively. $s, h, r$, and $c$ are the respective weights for the Fama French factors or portfolios (Fama and French 2014). $S M B_{t}, H M L_{t}, R M W_{t}$, and $C M A_{t}$ are all expected to have positive signs indicating that small cap, high book-to-market, profitable and conservative investment stocks will tend to outperform the market. The Fama French three-factor model does not employ the $R M W_{t}$ and $C M A_{t}$ factors.

\section{Carhart Model}

Carhart's (1997) four-factor model is also used as a performance benchmark. The Carhart four factor model is similar to the Fama-French three-factor model, but it includes an additional factor for momentum (UMD) or up minus down, which is the return difference between a portfolio of past 12-month winners and a portfolio of past 12-month losers. The four-factor model is consistent with a model of market equilibrium with four risk factors. The theory is that firms with positive momentum will outperform firms with negative momentum. The Carhart four-factor model is as follows:

$r_{t}=\alpha+\beta\left(R_{M t}-R_{F t}\right)+s S M B_{t}+h H M L_{t}+m U M D_{t}+e_{t}$

\section{Panel Regressions}

Since our sample size is small, we needed to do some additional analysis to confirm our findings. Using the same framework as we did with our time series regressions, we ran panel fixed effects regressions using the returns for all 85 plans. We ran regressions for the three-factor model and the other for the five-factor model.

The CAPM panel regression model is as follows:

$r_{i t}=\alpha_{i}+\beta_{i}\left(R_{M t}-R_{F t}\right)+e_{i t}$ 
The CAPM with the Barclays Aggregate US Bond Index panel regression model is as follows:

$r_{i t}=\alpha_{i}+\beta_{i}\left(R_{M t}-R_{F t}\right)+b_{i}$ Bond $_{t}+e_{i t}$

The Fama French three-factor panel regression model is as follows:

$r_{i t}=\alpha_{i}+\beta_{i}\left(R_{M t}-R_{F t}\right)+s_{i} S M B_{t}+h_{i} H M L_{t}+e_{i t}$

The Carhart four-factor panel regression model is as follows:

$r_{i t}=\alpha_{i}+\beta_{i}\left(R_{M t}-R_{F t}\right)+s_{i} S M B_{t}+h_{i} H M L_{t}+m_{i} U M D_{t}+e_{i t}$

The Fama French five-factor panel regression model is as follows:

$r_{i t}=\alpha_{i}+\beta_{i}\left(R_{M t}-R_{F t}\right)+s_{i} S M B_{t}+h_{i} H M L_{t}+r_{i} R M W_{t}+c_{i} C M A_{t}+e_{i t}$

where $r_{i t}$ is the excess return in plan i at time t, where i references one of the eighty-five pension plans in our data base, $\alpha_{i}$ represents the intercept term for plan $\mathrm{i}, b_{i}, s_{i}, h_{i}, m_{i}, r_{i}$, and $c_{i}$ are the respective weights for plan i, and $e_{i t}$ is the residual for plan i at time t. Again, the Fama French three-factor model and the Carhart four-factor model do not employ the $R M W_{t}$ and $C M A_{t}$ factors.

\section{Bootstrapped Alphas}

To complete our analysis, we use a bootstrapping procedure again using each of the models from our time series analysis to randomly generate alphas to determine if they are significantly different from zero. We utilize a five-step bootstrapping process to convince ourselves that our alphas are positive and significant. We perform the process on our four Fama French regressions described in Table I. The steps for three-factor Fama French model are out lined below. The model is follows:

$r_{t}=\alpha+\beta\left(R_{M t}-R_{F t}\right)+s S M B_{t}+h H M L_{t}+\varepsilon_{t}$

We test the null hypothesis i.e., $\alpha=0$. Note that if $\varepsilon_{t}$ is normally distributed, it would be unnecessary to do bootstrapping even with our small sample size. In our case, we resort to the finite-sample exact distribution of the test statistics to do the testing. The bootstrapping method eliminates concerns when you suspect the residuals are not normally distributed and when the sample size is small.

First, we impose the null hypothesis, $\alpha=0$ and estimate the restricted regressions model:

$r_{i t}=b_{i}\left(R_{M t}-R_{F t}\right)+s_{i} S M B_{t}+h_{i} H M L_{t}+\varepsilon_{i t}$

We record parameter estimates $\left\{\hat{\beta}_{i}, \hat{s}_{i}, \hat{h}_{i}, \hat{\sigma}^{2}\right\}$ and $\hat{\sigma}^{2}$ is the estimate of the variance of the residual $\varepsilon_{t}$. We also record the estimated residuals $\left\{\hat{\varepsilon}_{t}\right\}_{1}^{T}$ from the above restricted linear regression model and standardize the residuals to have zero mean and unit variance (that is $\tilde{\varepsilon}_{t}=\frac{\hat{\varepsilon}_{t}-\operatorname{avg}\left(\hat{\varepsilon}_{t}\right)}{\widehat{\sigma}}$ ).

Second, we bootstrap (generate) return data $\left\{\tilde{r}_{t}\right\}_{1}^{T}$ using the restricted model and the above parameter estimates:

$\tilde{r}_{i t}=\hat{b}_{i}\left(R_{M t}-R_{F t}\right)+\hat{s}_{i} S M B_{t}+\hat{h}_{i} H M L_{t}+\tilde{\varepsilon}_{i t}$

Here $\tilde{\varepsilon}_{t}$ is randomly sampled from our pool of $\left\{\tilde{\varepsilon}_{t}\right\}_{1}^{T}$ with replacement for the so-called "semiparametric bootstrapping" (specifically, for every time $t$, generate a random number (time indicator) that is uniformly distributed on the interval $[1, \mathrm{~T}]$ and use the $\tilde{\varepsilon}_{t}$ corresponding to that time point $t$ ). Use the generated returns data and estimate the unrestricted linear model: 


$$
r_{i t}=b_{i}\left(R_{M t}-R_{F t}\right)+s_{i} S M B_{t}+h_{i} H M L_{t}+\varepsilon_{i t}
$$

We record the t-statistic for $\hat{\alpha}$ and let us call it $t(\hat{\alpha})$. Third, we repeat step 2 ninety-nine times and obtain a collection of the test statistics: $\left\{t(\hat{\alpha})_{i}\right\}_{1}^{B}$. Fourth, we sort the collection of test statistics from the smallest to the largest and take the $95^{\text {th }}$ element as the $5 \%$ bootstrapped critical value. Finally, compare the t-statistics from our regressions in Table I for $\hat{\alpha}$ with this $5 \%$ bootstrapped critical value. If the actual t-test is greater than the $5 \%$ critical value, you would reject the null hypothesis.

\section{RESULTS}

First, we regressed the five models described above against our value-weighted and equal-weighted return data. In each regression we determine if alpha is positive and significant. The results of our time series regressions are shown in Table I. The alphas in all ten of our regressions are positive with varying levels of significance. We found that the alphas from our regressions with equal-weighted returns were either significant $(\mathrm{p} \leq .05)$ or highly significant $(\mathrm{p} \leq .01)$ in every case; however, the alphas from our regressions with value-weighted returns are positive and only marginally significant $(p \leq .10)$. We believe that these results indicate that the plans in our data set are as a whole outperforming the market. In addition, these results indicate that the smaller pension plans in our data set are outperforming the larger plans.

TABLE 1

EQUAL-WEIGHTED AND VALUE-WEIGHTED INVESTMENT RETURNS REGRESSED AGAINST THE MODELS

(1)

(2)

(3)

\section{CAPM/Bonds}

Equal Weighted

Value Weighted

Weighted

\begin{tabular}{lc} 
Variable & Weighted \\
\hline \hline alpha & 0.020 \\
& $(3.055)^{* * *}$ \\
mkt-rf & 0.610 \\
& $(17.370)$ \\
bond &
\end{tabular}

$\mathrm{smb}$

$\mathrm{hml}$

$(3.678)^{* * *}$

0.567

(17.230)
$(1.792)^{* *}$
0.612
(15.930)
0.038

(0.213)
(4)

(5)

Fama French

3-Factor

Value-Weighted

0.018

$(2.053)^{* *}$

0.616

(15.850)

(16.010)

0.079

(0.477)
$-0.016$

$-(0.129)$

0.034

(0.633)

umd

rmw

cma

\begin{tabular}{lccccc}
$\mathrm{N}$ & 14 & 14 & 14 & 14 & 14 \\
$\mathrm{r} 2$ & 0.962 & 0.961 & 0.962 & 0.962 & 0.964 \\
\hline \hline $\mathrm{ll}$ & 33.78 & 34.69 & 33.81 & 34.83 & 34.15 \\
$\mathrm{rmse}$ & 0.023 & 0.022 & 0.024 & 0.023 & 0.025 \\
\hline
\end{tabular}




\begin{tabular}{|c|c|c|c|c|c|}
\hline Variable & $\begin{array}{c}(6) \\
\text { Fama French } \\
\text { 3-Factor } \\
\text { Equal- } \\
\text { Weighted } \\
\end{array}$ & $\begin{array}{c}\text { (7) } \\
\text { Carhart } \\
\text { 4-Factor } \\
\text { Value- } \\
\text { Weighted } \\
\end{array}$ & $\begin{array}{c}\text { Carhart } \\
\text { 4-Factor Equal- } \\
\text { Weighted } \\
\end{array}$ & $\begin{array}{c}\text { Fama French } \\
\text { 5-Factor Value } \\
\text { Weighted } \\
\end{array}$ & $\begin{array}{c}\text { Fama French } \\
\text { 5-Factor Equal } \\
\text { Weighted } \\
\end{array}$ \\
\hline alpha & $\begin{array}{c}0.019 \\
(2.296)^{* *}\end{array}$ & $\begin{array}{c}0.017 \\
(1.882)^{* *}\end{array}$ & $\begin{array}{c}0.020 \\
(2.343)^{* *}\end{array}$ & $\begin{array}{c}0.021 \\
(1.987)^{* *}\end{array}$ & $\begin{array}{c}0.024 \\
(2.466)^{* *}\end{array}$ \\
\hline mkt-rf & $\begin{array}{c}0.574 \\
(15.810)\end{array}$ & $\begin{array}{c}0.616 \\
(15.100)\end{array}$ & $\begin{array}{c}0.575 \\
(15.480)\end{array}$ & $\begin{array}{c}0.585 \\
(9.775)\end{array}$ & $\begin{array}{c}0.530 \\
(9.743)\end{array}$ \\
\hline bond & & & & & \\
\hline $\mathrm{smb}$ & $\begin{array}{c}0.046 \\
(0.048)\end{array}$ & $\begin{array}{c}-0.004 \\
-(0.027)\end{array}$ & $\begin{array}{c}0.017 \\
(0.139)\end{array}$ & $\begin{array}{c}0.035 \\
(0.232)\end{array}$ & $\begin{array}{c}0.076 \\
(0.556)\end{array}$ \\
\hline $\mathrm{hml}$ & $\begin{array}{c}0.012 \\
(0.245)\end{array}$ & $\begin{array}{c}0.029 \\
(0.505)\end{array}$ & $\begin{array}{c}0.023 \\
(0.436)\end{array}$ & $\begin{array}{c}0.081 \\
(1.086)\end{array}$ & $\begin{array}{c}0.059 \\
(0.874)\end{array}$ \\
\hline umd & & $\begin{array}{c}0.010 \\
(0.284)\end{array}$ & $\begin{array}{c}-0.025 \\
(-0.762)\end{array}$ & & \\
\hline $\mathrm{rmw}$ & & & & $\begin{array}{c}-0.060 \\
(-0.513)\end{array}$ & $\begin{array}{c}-0.103 \\
(-0.975)\end{array}$ \\
\hline $\mathrm{cma}$ & & & & $\begin{array}{c}-0.068 \\
(-0.473)\end{array}$ & $\begin{array}{c}-0.021 \\
(-0.163)\end{array}$ \\
\hline $\mathrm{N}$ & 14 & 14 & 14 & 14 & 14 \\
\hline $\mathrm{r} 2$ & 0.963 & 0.964 & 0.966 & 0.968 & 0.969 \\
\hline 11 & 35.1 & 34.21 & 35.54 & 34.94 & 36.3 \\
\hline rmse & 0.023 & 0.026 & 0.024 & 0.026 & 0.024 \\
\hline
\end{tabular}

Note: Table 1 shows our equal-weighted and value-weighted investment returns regressed against the Capital Asset Pricing Model, the Capital Asset Pricing Model with the Barclay Aggregate Bond Index, Carhart four-factor model and the Fama French three and five-factor models. The respective t-statistics for each coefficient are shown below in parentheses.

In Table 1 the t-statistic for alpha ranges from a low of 1.8 to 3.7 indicating that alpha is positive and significant in all our time series regressions. The significance level for the respective alphas varies from a low of about $90 \%$ to highs above $99 \%$.

Next, we regressed the models against the individual returns of all 85 plans in our data set. In each regression we determine if alpha is positive and significant. The results of our panel regressions are shown in Table II. The alphas in all five of our panel regressions are positive and highly significant. In Table II the t-statistics for alpha range from a low of 5.8 to a high of 13.9 again indicating that alpha is positive and highly significant in all five panel regressions. 


\section{TABLE 2 \\ INDIVIDUAL INVESTMENT RETURNS OF ALL THE PLANS REGRESSED AGAINST THE MODELS}

\begin{tabular}{|c|c|c|c|c|c|}
\hline Variable & $\begin{array}{c}1) \\
\text { CAPM } \\
\end{array}$ & $\begin{array}{c}(2) \\
\text { CAPM/Bonds } \\
\end{array}$ & $\begin{array}{c}\text { (3) } \\
\text { Fama French 3- } \\
\text { Factor }\end{array}$ & $\begin{array}{c}(4) \\
\text { Carhart } \\
\text { 4-Factor } \\
\end{array}$ & $\begin{array}{c}\text { (5) } \\
\text { Fama French } \\
\text { 5-Factor } \\
\end{array}$ \\
\hline alpha & $\begin{array}{c}0.019 \\
13.850 * * *\end{array}$ & $\begin{array}{c}0.018 \\
8.758 * * *\end{array}$ & $\begin{array}{c}0.014 \\
8.348^{* * *}\end{array}$ & $\begin{array}{c}0.012 \\
7.532 * * *\end{array}$ & $\begin{array}{c}0.011 \\
5.838 * * *\end{array}$ \\
\hline mkt-rf & $\begin{array}{c}0.006 \\
(81.650)\end{array}$ & $\begin{array}{c}0.006 \\
(77.890)\end{array}$ & $\begin{array}{c}0.006 \\
(82.470)\end{array}$ & $\begin{array}{c}0.006 \\
(83.510)\end{array}$ & $\begin{array}{c}0.006 \\
(58.100)\end{array}$ \\
\hline bond & & $\begin{array}{c}0.032 \\
(0.880)\end{array}$ & & & \\
\hline $\mathrm{smb}$ & & & $\begin{array}{c}0.000 \\
(0.721)\end{array}$ & $\begin{array}{c}0.001 \\
(2.502)\end{array}$ & $\begin{array}{c}0.001 \\
(3.520)\end{array}$ \\
\hline $\mathrm{hml}$ & & & $\begin{array}{c}0.001 \\
(6.780)\end{array}$ & $\begin{array}{c}0.000 \\
(5.873)\end{array}$ & $\begin{array}{c}0.001 \\
(7.200)\end{array}$ \\
\hline umd & & & & $\begin{array}{c}0.041 \\
(6.182)\end{array}$ & \\
\hline $\mathrm{rmw}$ & & & & & $\begin{array}{c}0.001 \\
(2.643)\end{array}$ \\
\hline $\mathrm{cma}$ & & & & & $\begin{array}{c}-0.001 \\
(-5.363)\end{array}$ \\
\hline $\mathrm{N}$ & 1190 & 1190 & 1190 & 1190 & 1190 \\
\hline $\mathrm{r} 2$ & 0.858 & 0.858 & 0.864 & 0.869 & 0.868 \\
\hline 11 & 2026 & 2027 & 2053 & 2074 & 2069 \\
\hline rmse & 0.046 & 0.046 & 0.045 & 0.044 & 0.044 \\
\hline
\end{tabular}

Note: Table 2 shows the individual investment returns of all the plans regressed against the Capital Asset Pricing Model, the Capital Asset Pricing Model with the Barclay Aggregate Bond Index, Carhart four-factor model and the Fama French three and five-factor models. The respective t-statistics for each coefficient are shown below in parentheses.

Finally, we executed our bootstrapping process on our time series regressions. The results are detailed in Table III, which includes the t-statistics for alpha from our initial time series regressions the 10\%, $5 \%$ and $1 \%$ bootstrapped critical values t-statistics for alpha. The results of our bootstrapping process show that the t-statistic for alpha from our initial time series regressions are positive and significant at the $5 \%$ critical value or higher in six out ten regressions with the exceptions being our value-weighted regression. So, we reject the null hypothesis that alpha is equal to zero in our equal-weighted regressions. Our value-weighted time series regressions the $t$-statistic for alpha in this regression was significant at the $90 \%$ level; therefore, we cannot reject the null hypothesis here. These results support and enhance the conclusions drawn from our initial time series regressions. Namely that the apparent outperformance of smaller plans being supported by the relatively higher t-statistics for alpha in our regressions that utilize equal-weighted returns. Additionally, the results of our bootstrapping indicate that bonds or fixed income investments are driving our results. 
TABLE 3

TIME SERIES REGRESSIONS

\begin{tabular}{|c|c|c|c|c|c|}
\hline Variable & $\begin{array}{c}\text { CAPM Value- } \\
\text { Weighted }\end{array}$ & $\begin{array}{c}\text { CAPM Equal- } \\
\text { Weighted }\end{array}$ & $\begin{array}{c}(3) \\
\text { CAPM/Bonds } \\
\text { Value- } \\
\text { Weighted } \\
\end{array}$ & $\begin{array}{c}\text { (4) } \\
\text { CAPM/Bonds } \\
\text { Equal- } \\
\text { Weighted } \\
\end{array}$ & $\begin{array}{c}\text { (5) } \\
\text { Fama French } \\
\text { 3-Factor } \\
\text { Value- } \\
\text { Weighted } \\
\end{array}$ \\
\hline $\begin{array}{l}\text { t-statistic from } \\
\text { Time Series } \\
\text { Regression } \\
\text { Boos trapped } \\
\text { Critical Values } \\
\end{array}$ & $3.055 * * *$ & $3.678 * * *$ & $1.792^{*}$ & $2.012 * *$ & $2.053^{*}$ \\
\hline $90^{\text {th }}$ percentile & 1.580 & 1.622 & 1.707 & 1.266 & 1.487 \\
\hline $95^{\text {th }}$ percentile & 1.957 & 3.322 & 1.974 & 1.629 & 2.115 \\
\hline \multirow[t]{2}{*}{$99^{\text {th }}$ percentile } & 2.688 & 3.353 & 3.595 & 2.2534 & 3.786 \\
\hline & $\begin{array}{c}\text { (6) } \\
\text { Fama French } \\
\text { 3-Factor } \\
\text { Equal- } \\
\text { Weighted } \\
\end{array}$ & $\begin{array}{c}(7) \\
\text { Carhart } \\
\text { 4-Factor Value- } \\
\text { Weighted } \\
\end{array}$ & $\begin{array}{c}(8) \\
\text { Carhart } \\
\text { 4-Factor Equal- } \\
\text { Weighted } \\
\end{array}$ & $\begin{array}{c}(9) \\
\text { Fama French } \\
\text { 5-Factor } \\
\text { Value- } \\
\text { Weighted } \\
\end{array}$ & $\begin{array}{c}(10) \\
\text { Fama French } \\
\text { 5-Factor } \\
\text { Equal- } \\
\text { Weighted } \\
\end{array}$ \\
\hline $\begin{array}{l}\mathrm{t} \text {-statistic from } \\
\text { Time Series } \\
\text { Regression } \\
\text { Boos trapped } \\
\text { Critical Values }\end{array}$ & $2.296 * * *$ & $1.882 *$ & $2.343 * *$ & $1.987^{*}$ & $2.466 * *$ \\
\hline $90^{\text {th }}$ percentile & 1.537 & 1.710 & 1.272 & 1.580 & 1.293 \\
\hline $95^{\text {th }}$ percentile & 1.872 & 2.626 & 2.019 & 2.713 & 1.552 \\
\hline $99^{\text {th }}$ percentile & 2.226 & 3.114 & 2.525 & 3.114 & 2.494 \\
\hline
\end{tabular}

Note: Table III shows the t-statistics for alpha in each of our time series regressions and the corresponding significance levels resulting from our bootstrapped alphas.

\section{CONCLUSION}

In our prior essay we found that state public pension plan investments had consistently outperformed the market in most cases on both an absolute basis. These findings inspired us to take a closer look at our investment data. The CAPM and the CAPM with the Barclays Aggregate Bond Index, the Fama French three and five-factor models, and the Carhart four-factor model were the perfect choice for our analysis because they collectively add six market anomalies to the analysis in addition to the excess returns on the market. The three-factor model includes firm size and book-to-market value to the analysis while the fivefactor model adds profitability and investment type, conservative vs. aggressive. The Carhart four-factor model adds momentum to the Fama French three-factor model.

Our analysis included three stages; first, time series regressions on the cumulative value-weighted and equal-weighted investment returns, second, panel regressions using the individual investment returns from all 85 plans in our data set and finally, we employed a bootstrapping process to confirm the results of our first two sets of regressions. At each stage, we are concerned with the $\alpha$ resulting from each regression. Positive and significant alpha is an indication that our investment returns are in fact beating the market. Our initial analysis included ten regressions using two set of investment returns and five models, five panel 
regressions using the same five models and a bootstrapping process on each of the time series regressions. We found that the alphas from both our time series and panel regressions were all positive and significant. In our bootstrapping process we were able to reject the null hypothesis $(\alpha=0)$ in six out of ten regressions. We can conclude from these results that the investment returns from the plans in our data set are beating the market i.e., state pension investments are generating positive alphas. Additionally, we found that the investment performance of relatively smaller plans in our data set was superior to that of the relative larger

plans and we found that the positive alphas in all our regressions were in part due to fixed income investments.

\section{REFERENCES}

Andonov, A., Bauer, R., \& Cremers, M. (2014). Pension fund asset allocation and liability discount rates. The Review of Financial Studies, 30(8), 2555-2595.

Carhart, M.M. (1997). On persistence in mutual fund performance. The Journal of Finance, 52(1), 57-82.

Fama, E.F., \& French, K.R. (1993). Common risk factors in the returns on stocks and bonds. Journal of Financial Economics, 33(1), 3-56.

Fama, E.F., \& French, K.R. (2015). A five-factor asset pricing model. Journal of Financial Economics, $116(1), 1-22$.

Hanby, M., Tennant, R., Kanuri, S., \& McLeod, R. (2019). State Pension Reform: What Have They Accomplished? Journal of Accounting and Finance, 19(8), 62-77.

Mohan, N., \& Zhang, T. (2014). An analysis of risk-taking behavior for public defined benefit pension plans. Journal of Banking \& Finance, 40, 403-419.

Pennacchi, G., \& Rastad, M. (2011). Portfolio allocation for public pension funds. Journal of Pension Economics \& Finance, 10(2), 221-245.

Sharpe, W.F. (1964). Capital asset prices: A theory of market equilibrium under conditions of risk. The Journal of Finance, 19(3), 425-442. 